\title{
Effects of Synthetic Rat C-Peptide in Normal and Diabetic Rats
}

\author{
Cz. Wójcikowski ${ }^{1}$, V. Maier ${ }^{2}$, K. Dominiak ${ }^{1}$, R. Fussgänger ${ }^{2}$ and E.F.Pfeiffer ${ }^{2}$ \\ ${ }^{1}$ Laboratory of Endocrinology, Institute of Obstetrics and Gynecology, Medical Academy, Gdańsk, Poland and \\ ${ }^{2}$ Department of Internal Medicine I, University of Ulm, FRG
}

\begin{abstract}
Summary. The effects of synthetic rat C-peptide 1 and C-peptide 2 on plasma insulin and blood glucose concentrations in the rat were studied. Infusion of rat C-peptide $\left(500 \mathrm{ug} \cdot \mathrm{h}^{-1}\right.$. $\mathrm{kg}^{-1}$ ) diminished glucose induced increase of plasma insulin by $56 \%(15.2 \pm 0.9$ versus $6.6 \pm 0.6 \mathrm{ng} / \mathrm{ml}, p<0.01$, mean \pm SEM). Somatostatin infused at a rate of $50 \mu \mathrm{g} \cdot \mathrm{h}^{-1} \cdot \mathrm{kg}^{-1}$ body weight inhibited glucose-induced insulin secretion by $33 \%$. In the presence of a mixture of both C-peptides or somatostatin,
\end{abstract}

blood glucose after intravenous glucose was higher than in the control experiments. In alloxan-diabetic rats, C-peptide $(160 \mu \mathrm{g} / \mathrm{kg})$ significantly increased and prolonged the hypoglycaemic effect of exogenous insulin. It is suggested that C-peptide may not be a biologically inert substance.

Key words: C-peptide, insulin secretion, effect of insulin, alloxan-diabetic rats, $\mathrm{C}$-peptide effect in vivo, somatostatin.
Although C-peptide is produced and released from the pancreas in an equimolar concentration to insulin, no definite biological activity has been identified [1]. Several studies failed to show any effect of C-peptide on glucose and lipid metabolism or on insulin secretion $[2,3]$. On the other hand, studies in vitro suggest that synthetic rat C-peptide inhibits glucose-induced insulin secretion from rat pancreas $[4,5]$. Moreover, Wójcikowski et al. have demonstrated that rat and human C-peptide decrease the release of insulin and glucagon from the isolated perfused rat pancreas $[6,7]$. In spite of the inhibition of insulin secretion, C-peptide had no influence on the incorporation of tritiated leucine into proinsulin [8].

The present studies were undertaken to define the action of rat C-peptides on glucose tolerance and insulin release in the rat in vivo.

\section{Materials und Methods}

Male Wistar rats, $180-230 \mathrm{~g}$ body weight, fed on a normal laboratory diet, were used throughout all experiments.

\section{Normal Rats}

The animals were anaesthetized by intraperitoneal injection of pentobarbital ( $40 \mathrm{mg} / \mathrm{kg}$ body weight). The femoral artery and vein were cannulated for blood sampling and infusions of $154 \mathrm{mmol} / 1 \mathrm{NaCl}, \mathrm{C}-$ peptide or somatostatin. A mixture $(1: 1)$ of rat C-peptide 1 and 2 $\left(500 \mu \mathrm{g} \cdot \mathrm{h}^{-1} \cdot \mathrm{kg}^{-1}\right.$ body weight) or somatostatin $\left(50 \mu \mathrm{g} \cdot \mathrm{h}^{-1} \cdot \mathrm{kg}^{-1}\right.$ body weight) in $154 \mathrm{mmol} / \mathrm{NaCl}$ was infused immediately after collection of the first blood sample at 0 time. In control experiments,
$\mathrm{NaCl}$ was infused at the rate $0.07 \mathrm{ml} / \mathrm{min}$. The infusions were continued throughout the experiments. Glucose $(500 \mathrm{mg} / \mathrm{kg}$ body weight $)$ was administered at $20 \mathrm{~min}$ as an intravenous bolus. Samples of blood $(0.3 \mathrm{ml})$ were taken from the femoral artery for glucose and insulin determination.

\section{Diabetic Rats}

Diabetes was induced by a single intravenous injection of alloxan monohydrate ( $35 \mathrm{mg} / \mathrm{kg}$ body weight) dissolved in $154 \mathrm{mmol} / 1 \mathrm{NaCl}$. After 2 weeks the blood glucose of the animals was elevated $>$ $15 \mathrm{mmol} / 1$ glucose. A mixture $(1: 1)$ of rat C-peptide 1 and 2 at the dose $80 \mu \mathrm{g} / \mathrm{kg}$ body weight was injected twice into the tail vein. $\mathrm{C}$-peptide was administered $30 \mathrm{~min}$ before the injection of insulin and afterwards together with insulin ( $1 \mathrm{U} / \mathrm{kg}$ body weight).

Insulin was determined by a radioimmunological method using dextran-coated charcoal to separate the free antigen [9]. Synthetic rat C-peptides at concentrations $\leqslant 1 \mu \mathrm{g} / \mathrm{ml}$ did not interfere in insulin determination. Rat insulin (Novo, Bagsvaerd, Denmark) was used as a standard. Blood glucose was measured by the ortho-toluidine method.

The results are expressed as mean \pm SEM. Statistical differences between means were determined by Student's t-test. The plasma insulin concentrations were transformed logarithmically before analysis by the Student's t-test. Synthetic rat C-peptide 1 (Lot. No. NY-YI4-34) and rat C-peptide 2 (Lot. No. NY-YI-4-48) were kindly donated by Professor N. Yanaihara, Shizuoka, Japan. The purity of the synthetic rat C-peptides was characterized previously [10].

\section{Results}

The infusion of a mixture of rat C-peptide 1 and 2 or somatostatin had no significant effect on fasting plasma 

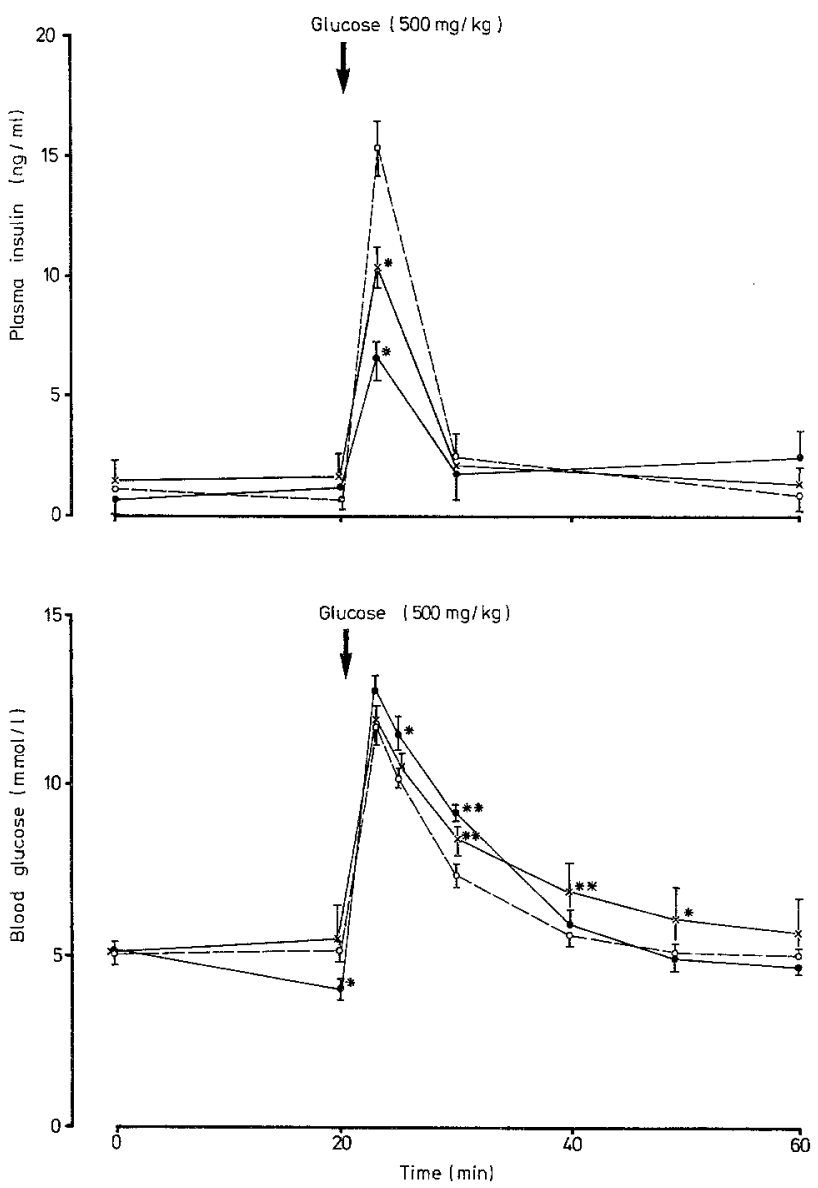

Fig.1. The plasma insulin and blood glucose responses to intravenous glucose injection during infusion of $154 \mathrm{mmol} / 1 \mathrm{NaCl}\left(\mathrm{O}_{---} \mathrm{O}\right)$, rat C-peptides $(\longrightarrow$ ) or somatostatin $(x-x)$ into normal rats $(n=6) . p$ values refer to differences between the value during infusion of $154 \mathrm{mmol} / 1 \mathrm{NaCl}$ and rat $\mathrm{C}$-peptides or somatostatin $\left(^{*} p<0.05\right.$, $\left.{ }^{* *} p<0.01\right)$.

insulin levels (Fig.1). However, the increase of plasma insulin induced by intravenous glucose in the presence of C-peptide was reduced by $56 \%(15.2 \pm 0.9$ versus $6.6 \pm 0.6 \mathrm{ng} / \mathrm{ml}, p<0.01)$, whereas a reduction of only $36 \%$ was observed in the presence of somatostatin. The blood glucose concentrations remained stable in rats receiving an infusion of $154 \mathrm{mmol} / 1 \mathrm{NaCl}$ or somatostatin but in the presence of rat C-peptide it significantly decreased at $20 \mathrm{~min}$ from $5.1 \pm 0.14$ to $4.3 \pm 0.22 \mathrm{mmol} / 1$ $(p<0.05)$. Blood glucose, after intravenous injection of $500 \mathrm{mg} / \mathrm{kg}$ body weight of glucose in rats receiving Cpeptide, was significantly higher only at 5 and $10 \mathrm{~min}$ after the intravenous glucose tolerance test than in animals given glucose alone. The mean blood glucose levels in rats infused simultaneously with somatostatin and glucose were higher at $10 \mathrm{~min}(p<0.01), 20 \mathrm{~min}(p<$ $0.01)$ and $30 \mathrm{~min}(p<0.05)$ after glucose administration. Intravenous injection of insulin ( $1 \mathrm{U} / \mathrm{kg}$ body weight) decreased blood glucose in alloxan-diabetic rats from $25.3 \pm 1.42$ to $19.3 \pm 0.71 \mathrm{mmol} / 1$ at $60 \mathrm{~min}$ (Fig. 2). In animals pretreated with C-peptide, blood glucose following injection of insulin decreased from $24.6 \pm 0.59$ to

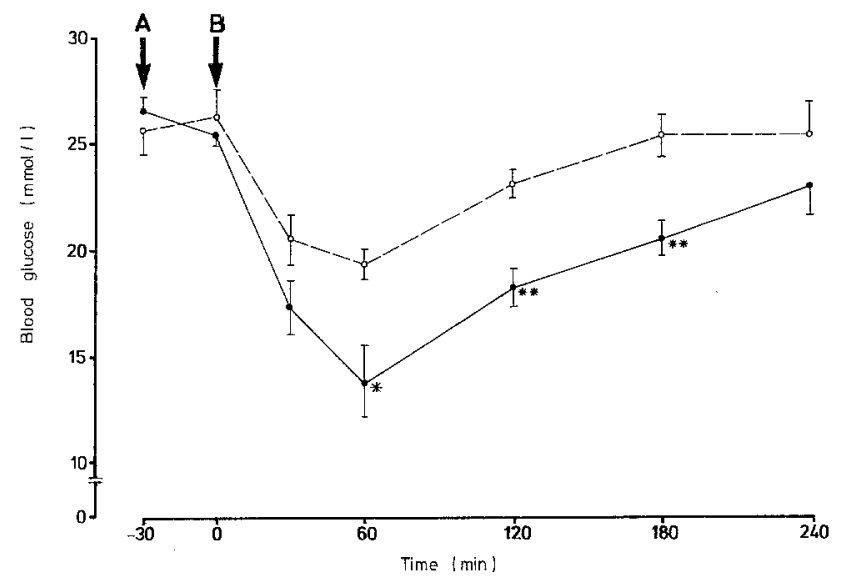

Fig. 2. The effect of rat C-peptides on hypoglycaemic activity of insulin in alloxan-diabetic rats $(n=6)$. $p$ values refer to differences between the value following injection of insulin and insulin + C-peptides $(* p<0.02, * * p<0.01)$.

$A$ : intravenous injection of $154 \mathrm{mmol} / 1 \mathrm{NaCl}(\mathrm{O} \ldots-\mathrm{O})$ or rat C-peptide (-) $B$ : intravenous injection of insulin $\left(\mathrm{O}_{---} \mathrm{O}\right)$ or insulin + rat C-peptide (

$13.7 \pm 1.57 \mathrm{mmol} / 1$. The hypoglycaemic effect of insulin alone persisted only $120 \mathrm{~min}$, whereas it was prolonged for $240 \mathrm{~min}$ if C-peptide was present additionally.

\section{Discussion}

The present finding confirms the previous results in vitro of the inhibitory effect of synthetic rat C-peptide on insulin release $[6,7]$. In contrast to our experiments on insulin secretion are the results of Kaneko et al. [11] who found no effect of dog C-peptide on glucose-induced insulin secretion in the dog. This discrepancy may be dependent on the species differences or upon the doses of C-peptide administered. In the dog, C-peptide was infused into the pancreatic artery by adjusting the concentrations to $25 \mathrm{ng} / \mathrm{ml}$ in the pancreatic vein in a basal state. In our experiments with rats the effect of C-peptide on insulin release in vivo as well as in vitro was observed at higher concentrations. C-peptide, however, is released by the $B$ cells of the pancreas and for a direct effect on pancreatic islets the local concentration may be more important than the concentration in peripheral blood. As it has been calculated [6], the maximum concentration of C-peptide in the extracellular space of rat islets is extremely high, approximately $10 \mu \mathrm{mol} / 1$.

In spite of a stronger inhibition of glucose-induced insulin release by rat $\mathrm{C}$-peptide than that effected by somatostatin, the blood glucose concentrations appeared higher than those in control experiments only in the first $10 \mathrm{~min}$. This fact, as well as a decrease of blood glucose concentrations following rat C-peptide administration which was observed also in concentrations corresponding to the physiological range [12], may indicate a hypoglycaemic action of C-peptide itself or an increase of hypoglycaemic activity of insulin through the 
C-peptide. Hence, we tested the effect of rat C-peptides administrated in a low dose, on the hypoglycaemic activity of insulin in alloxan-diabetic rats. The lack of a significant effect of C-peptide alone and a greater and prolonged decrease of blood glucose concentrations after insulin injection could be interpreted as an increase in the hypoglycaemic activity of insulin in the presence of synthetic rat C-peptides. Although the action mechanism may be different, it cannot be excluded that the insulin binding to receptors becomes increased or that insulin degradation is decreased.

Acknowledgments. We appreciate the active support of Professor N. Yanaihara, Shizuoka College of Pharmacy, Shizuoka, Japan. This work was supported by Deutsche Forschungsgemeinschaft, SFB 87/G-3, Endocrinologie, Ulm. Cz. Wojcikowski was a fellow of the Alexander von Humboldt-Stiftung (1977/78 and 1980/81) at the Department of Internal Medicine I, University of Ulm.

\section{References}

1. Kitabchi AE (1977) Proinsulin and C-peptide. A review. Metabolism 26: $547-587$

2. Kitabchi AE (1970) The biological and immunological properties of pork and beef insulin, proinsulin and connecting peptides. J Clin Invest 49: 979-987

3. Dunbar JC, McLaughlin WJ, Walsh MF, Foa PP (1976) Insulin secretion and glucose uptake by isolated islets of the hamster. Effect of insulin, proinsulin and C-peptide. Horm Metab Res 8: 1-6

4. Toyota T, Abe K, Kudo M, Kimura K, Goto Y (1975) Inhibitory effects of synthetic rat $\mathrm{C}$-peptide 1 on insulin secretion in the isolated perfused rat pancreas. Tohoku J Exp Med 117: 79-83

5. Toyota T, Abe K, Kudo M (1977) Inhibitory action of rat insulin and synthetic rat $\mathrm{C}$-peptide on insulin secretion in the perfused rat pancreas. Acta Diabetol Lat 14: 250-256

6. Wójcikowski Cz, Fussgänger RD, Pfeiffer EF (1977) Inhibition of insulin and glucagon secretion of the isolated rat pancreas by synthetic human and rat C-peptide. In: Beyer J, Krause U, Naegele W (eds) C-peptide. Schnetztor-Verlag, Konstanz, pp 75-88

7. Wójcikowski Cz. Fussgänger RD, Pfeiffer EF (1977) The effect of synthetic human and rat C-peptides on insulin and glucagon secretion of the isolated perfused rat pancreas. Diabetologia 13: 440 (Abstract)

8. Klier M, Wójcikowski Cz, Maier V (1977) Abolition of the inhibitory effect of C-peptides on insulin secretion in isolated pancreatic islets of rats by cAMP. Diabetologia 13:408-409 (Abstract)

9. Herbert V, Lau KS, Gottlieb CW, Bleicher SJ (1965) Coated charcoal immunoassay of insulin. J Clin Endocr 25: 1375-1384

10. Yanaihara N, Sakagami M, Sakura N, lizuka Y, Nishida T, Hashimoto T, Yanaihara C (1977) Synthetic C-peptides and proinsulin synthethis. In: Bajaj JS (ed) Diabetes. Excerpta Medica, Amsterdam, pp 116-125

11. Kaneko T, Kaneto A, Yanaihara N, Yasuda H, Suzuki S, Oka H, Oda T (1979) Insulin and C-peptide secretion in animals. In: Baba S, Kaneko T, Yanaihara N (eds) Proceedings of the Symposium on proinsulin, insulin and C-peptide, Tokushima. Excerpta Medica, Amsterdam Oxford, pp 138-147

12. Dryburgh JR, Hampton SM, Marks V (1980) Endocrine pancreatic control of the release of gastric inhibitory polypeptide. A possible physiological role for C-peptide. Diabetologia 19: 397-401

Received: 19 October 1982

and in revised form: 20 May 1983

Assistant Professor Cz. Wójcikowski

Laboratory of Endocrinology

Institute of Obstetrics and Gynecology

Medical Academy

Kliniczna $1 \mathrm{a}$

PL-80-402 Gdańsk

Poland 